\title{
Chronic obstructive pulmonary disease in non-smokers: An Update
}

\author{
Alcibey Alvarado* \\ Internal Medicine and Neumology, Clínica de Diagnóstico Médico, San José, Costa Rica
}

\begin{abstract}
Chronic obstructive pulmonary disease (COPD) is a leading cause of morbidity and mortality worldwide. Tobacco smoking is established as a major risk factor. However, especially in the last 15 years, there are studies have shown that long-term exposure to biomass fuel smoke to cook and heat homes, also carries a high risk for the development of COPD. This occurs particularly in developing countries, and women and children have the highest exposure rates and are therefore more likely to develop the disease. It is estimated that $25-45 \%$ of patients with COPD have never smoked and the burden of COPD not associated with smoking is possibly higher than previously believed. Although exposure to biomass is the major risk factor for COPD not associated with smoking, there are other associated factors such as occupational exposure to dust and gases, history of pulmonary tuberculosis, HIV/AIDS, lower respiratory tract infection (particularly in the childhood), chronic asthma, external pollution and poverty. This review exposes the evidence of this association, and some clinical, functional, anatomopathological and therapeutic aspects and particularly the need for preventive interventions to face this other side of the entity that seems to be increasing.
\end{abstract}

\section{Introduction}

COPD is characterized by progressive airway flow obstruction and destruction of lung parenchyma, due to an inflammatory response and tissue damage, caused by chronic exposure to environmental factors in genetically susceptible individuals [1]. Susceptibility to COPD may depend on genetic reprogramming, inherent genetic susceptibility or intrinsic differences in lung structure [2-4]. Tobacco smoking was associated with risk of COPD as early as in 1950s [5,6]; smoking was established as a causal risk factor by the work of Fletcher and Peto in a prospective study of 729 men [7] and then confirmed by the larger and longer Framingham study [8]. Smokers lose at least one decade of life expectancy, as compared with those who have never smoked, and cessation before age 40 years reduces the risk of death associated with continued smoking by about $90 \%$ [9]. Smoking causes $25 \%$ of all deaths among men and women between 35-69 years in the United States of America (US) [10]. COPD is a high prevalent disease, with prevalence in people over 40 years of $10.1 \%$ worldwide and it will become the third cause of death in the world in 2020 and will become the seventh largest burden in 2030 [11,12]. It is estimated that in 2010 number of COPD globally amounted to 384 million, with 3 million deaths annually. With the increase in smoking in developing countries, and with the increase in life expectancy in high-income countries, the prevalence of COPD is expected to increase over the next 30 years and to exceed 4.5 million deaths per year in both COPD and related conditions [13]. In the US, COPD is the second cause of death [14]. Consequently, many of the COPD prevalence studies have been conducted and continue to be carried out mainly in cigarette smokers, and many clinical studies recruit only smokers with at least 10-20 packets-year of exposure to smoking $[11,15,16]$.

However, in the last three decades and particularly in the past 15 years, the number of publications about other risk factors associated with COPD has increased, such as exposure to indoor and outdoor air pollution, occupational exposure to dust and fumes, history of repeated lower respiratory tract infections during childhood, HIV / AIDS, pulmonary tuberculosis, asthma, intrauterine growth retardation, malnutrition and poverty [17]. This monograph is therefore intended to update the topic of COPD in non-smokers.

\section{Evidence of COPD in non-smokers}

Fairbairn in 1958 and Phillips in 1963 had already reported that other risk factors, besides tobacco, were associated with COPD $[18,19]$. In 1987, Husman associated COPD with work in farms in a study with Finnish farmers [20]. The NHANES III study reported a $6.6 \%$ prevalence of COPD in non-smokers and with a spirometric diagnosis of COPD, unlike the previous studies NHANES I, NAHNES II and HHANES in which the diagnosis was based on self-supervised physician diagnosis [21]. The study findings also suggested that $25 \%$ of COPD cases in the US occurred in non-smoking patients, which was similar to those reported in the United Kingdom (UK) and Spain [2224]. In 2009, Salvi and Barnes presented 21 well-consolidated reports in different parts of the world about the prevalence of COPD in nonsmokers and a broad casuistry of the proportion of patients with COPD not associated with smoking worldwide [17]. Since then, work on the topic has been growing and it is possible that the prevalence of this entity is different from that reported by strictly epidemiological studies, as shown by the works of China, Korea, Japan, Uganda, South Africa, Brazil, Chile, Mexico, Uruguay, Venezuela, Colombia and Asia-Pacific to use only a few examples [25-32].

The detail with these studies is that they are fundamentally epidemiological. Unlike cigarette-induced COPD, where researchers

Correspondence to: Alcibey Alvarado, Clínica de Diagnóstico Médico, Torre Médica. 3 piso. Paseo Colón, San José, Costa Rica, Tel: 50622237134, 50622566439, 50687351858; Fax: 50622216754; E-mail address: alcialvagonza@ yahoo.com.mx

Key words: COPD non-smoker, biomass, indoor air pollution

Received: March 03, 2018; Accepted: March 24, 2018; Published: March 29, 2018 
can choose the type of cigarette (or the chemical constituent to be investigated), such as the $1 \mathrm{R} 6 \mathrm{~F}$ available from the Center for Tobacco Reference Products produced by the University of Kentucky, there are no references biomass fuels available specifically made for research purposes. Exposure to biomass from in vitro and in vivo studies has a lot of variability in exposure time, exposure to bacteria and other inhaled materials, temperature, origin of the biomass, device used for exposure, etc. Very recently Capistrano et al. have described a method used for 5 years at the School of Life Sciences, University of Sydney, Australia, to try to standardize the research technique of biomass exposure [1,33].

\section{Indoor air pollution}

\section{Biomass}

Indoor fuels include solid fuels, liquids and gases. The solid fuels are biomass and coal. Globally $50 \%$ of all households and $90 \%$ of rural households use biomass as fuel. Biomass refers to materials of vegetable or animal origin used as fuels and include wood, twigs, charcoal (a product of incomplete combustion of wood), grass, crop residues (e.g. corn husk, straw, bagasse-biomass remaining after processing sugar-cane) and animal dung [34]. Coal, as distinct from charcoal, is a fossil fuel that occurs naturally formed of organic material preserved, metamorphosed and compressed. Liquid fuel includes kerosene and liquefied petroleum gas (LPG). Gas fuel includes methane and natural gas. Biomass smoke is the leading environmental risk factor worldwide. About 3 million people, half of the world's population, are exposed to biomass smoke compared to 1.01 million people who smoke tobacco, which suggests that exposure to biomass smoke may be the biggest risk factor for COPD globally [24]. Approximately 2 billion $\mathrm{kg}$ of biomass per day are burned in developing countries [17], mainly associated with $\mathrm{COPD}$ and acute lower respiratory tract infection and responsible for 4 million deaths annually around the globe [35]. The fundamental reason for the use of biomass as a fuel is poverty since it is cheaper than LPG or electricity which are the cleanest sources of energy and it is predictable that the domestic consumption of biomass fuels will increase or remain substantially elevated in the decades future, particularly in rural areas $[36,37]$.

In developing countries, women and children are the most exposed due to cultural reasons and the fact that they cook inside poorly ventilated houses without chimneys or pipes, which lead to the particles of combustion, catch and diffuse in closed or badly ventilated spaces [38]. During the incineration of these fuels, people who remain indoors are exposed to levels of up to $30,000 \mu \mathrm{g} / \mathrm{m}^{3}$ of particulate matter (PM) of $<10 \mu \mathrm{m}$ in diameter, and the average levels throughout the day are of $300-5,000 \mu \mathrm{g} / \mathrm{m}^{3}$ [39], when the WHO recommendation for PM10 is to be $<50 \mu \mathrm{g} / \mathrm{m}^{3}$ for 24 hours [35]. Since more than a decade ago, it was reported that around $50 \%$ of COPD deaths in developing countries were attributable to biomass smoke, of which $75 \%$ occurred in women [40]. The Global Burden of Disease 2010 study found that air pollution in homes is the second highest risk factor for disease in women and girls [41]. More than $80 \%$ of households in China, India and subSaharan Africa use biomass fuels for cooking, and in rural areas of Latin America, the proportion varies between 30-75\%.

Even in some developed countries, such as Canada, Australia and the western states of the US, the persistent increase in energy costs has promoted the increase in the number of households that use wood and other types of biomass products to heat the home [42]. In developed countries the use of biomass increases during periods of recession [43], however, it is more seasonal because the main use is to heat homes and children's exposure is lower since they are in schools, and fundamentally at the rural level. The use of interior wood as fuel is seen as cheaper, renewable, and possibly more "natural" and therefore an alternative to electricity in developed countries increasing exposure to biomass smoke [44]. There are also significant differences between the stoves used in developed and developing countries. In developed countries the use of the stove is mainly to heat the stay, there is low exposure, both sexes exposed, basically wood is used and generally only one material and the stoves have a chimney. In developing countries the original objective is to cook, there are high levels of exposure, generally more than one fuel, women and children are more exposed, and stoves have no chimneys [45]. With regard to cooking, in developed countries, biomass is used to flavor foods during the process (barbecues, smoked meats or wood-fired pizza). Outside of homes, some occupations such as firefighters involve high exposures to biomass smoke as well as the attention of forest fires [46].

\section{COPD and biomass}

In the last three decades many studies have identified exposure to biomass smoke as a primary risk factor for COPD. These studies have shown the increased prevalence of respiratory symptoms in women who use biomass for cooking and the greater decline in lung function with respect to women who are not exposed [47-53]. Pérez-Padilla and collaborators showed that the adjusted odd ratio for exposure to 100 hours-year (is an index of exposure to domestic wood smoke in which the number of hours per day of exposure is multiplied by the years) was 9.3 and 15 for a 200-hour-year exposure in Mexican women [54]. Köksal and colleagues in a study of 51 women from Turkey, nonsmokers, found a greater fall in FEV1 at higher hours-year exposure to wood smoke (province of Middle Anatolia and Dead Sea) and to dung (Eastern Anatolia) [55]. Sood and co-workers studied the association between exposure to wood smoke and the prevalence of COPD (spirometric criteria) in 2012 adults living in New Mexico, USA. They reported that exposure to wood smoke was associated with 70\% (95\% CI 30-220) increased risk of having COPD in both men and women. Therefore, even in developed countries such as the US could have a substantial burden of COPD associated with biomass fuel [56].

\section{Biomass smoke}

The efficiency of the combustion of biomass as a fuel is very low, leading to high concentrations inside homes of substances dangerous to health. The most efficient domestic fuels have decreased pollution but are the most expensive. Electricity is the most efficient. Dried animal dung, twigs, and grass are the cheapest, the least efficient and those that produce more pollution. Crop residues, wood, and charcoal are intermediate efficiency and kerosene, coal, and bottled or piped gas are the most efficient combustible, although below electricity [57]. Biomass smoke contains around 200 different components, which include a significant number of toxics such as CO, PM10, sulfur dioxide and nitrogen, polycyclic aromatic hydrocarbons (PAH), aldehydes, free radicals and non-radical oxidizing species, volatile organic compounds, formaldehyde, chlorinated dioxins and endotoxins (particularly when burning maize crop residue and cow dung) [58]. The exposure to toxic doses of these substances during the combustion of biomass is more than proven. Previously, we explained what happens with $\mathrm{PM}<10$. Another example, the US Environmental Protection Agency (EPA) defines as a safety standard that exposure to $\mathrm{CO}$ should not be greater than 10 parts per million (ppm) in 8 hours. In households where biomass is used as a fuel, the exposure in 24 hours can be $2-50 \mathrm{ppm}$, and when cooking it is 10-500 ppm [59]. It is estimated that contribute to the annual deaths of 2 million women and children [60-63]. 


\section{Risk for babies and children}

In underdeveloped or developing countries women are the most exposed because traditionally they are responsible for cooking, and infants and small children too, as they often carry them on their backs during domestic chores. Typically exposure to high concentrations of domestic pollution ranges from 1-7 hours per day for many years, initiating exposure at very early ages and even in utero [60]. Children of mothers exposed to biomass in open stoves have birth weights 60 $70 \mathrm{~g}$ lower than those exposed to stovepipe pollution, electricity or gas [59]. Low weight is an independent risk factor for COPD that has been associated with poor growth and lung function during childhood and adolescence [61].

Indoor air pollution from the use of wood, animal dung and other fuels is a risk factor for acute lower respiratory tract infection. In 2008, pneumonia was reported as the leading cause of death in children under 5 years of age, with 1.8 million deaths annually, mainly in developing countries [62]. Children who survive these infections are more likely to have dysfunctional lungs that predispose, in the future, to the development of COPD. Malnutrition and low socioeconomic status are also risk factors for COPD in this population.

\section{Outdoor air pollution}

The contribution of outdoor air pollution to COPD was investigated in 1958 in the UK in postmen, in whom it was shown that the prevalence of COPD was higher in those who worked in areas with greater pollution than in those who worked in less polluted areas, and the association was independent of smoking [18], which was confirmed in a later study, also by mail carriers [64], and then in the general population in the UK and US, in people who lived near roads with high vehicular traffic [65-68]. In the last three decades, air pollution has decreased substantially in many cities in developed countries, but has increased in developing countries (e.g., Asia, Africa and South America), due to the growing industry and traffic congestion.

It is obvious that, as in COPD associated with smoking, prevention is essential to reduce the impact of exposure to inhalants, as shown by the recent work of Gaudeman and collaborators in Los Angeles (USA). By reducing environmental and photochemical pollution (NO2, $\mathrm{PM}<2.5$ and $\mathrm{PM}<10$ ) there were beneficial, statistically significant effects on the growth of lung function in children born after the decline of contamination [69]. The reduced pulmonary function is a powerful predictor not only of chronic respiratory disease, but also of chronic cardiovascular disease and mortality [70]. Throughout the globe the intentional use of fire as part of agricultural practices is another source of biomass smoke, and the same is true of forest fires. With the undeniable march of climate change, the risk of forest fires has increased around the planet, with fires occurring in areas as diverse as Chile, Indonesia, Canada, Portugal, Pakistan, Russia, Australia and USA. The population is exposed mainly to PM and $\mathrm{CO}$ with forest fires, and to a lesser degree to acrolein, benzene and formaldehyde [71]. Exposure to airborne pollutants in Asian countries, which predominates in urban and industrialized areas compared to rural and agricultural areas, has been considered a contributor to chronic cough in the continent [72].

There is an association between exacerbations of COPD and exposure to not only internal pollutants but also to external pollution and an increase in hospital admissions [73,74].

\section{Occupational exposures}

The fraction of the population with COPD attributable to occupational exposure varies between $9-31 \%$, but the real risk is not clearly known, particularly in developing countries, given that the epidemiological definition of this type of COPD has not been adequately standardized [75]. Epidemiological studies should be complemented with experimental studies to provide a mechanism to explain the findings of epidemiological studies. Initial observations in this field strongly associated COPD with exposure to toxic gases, grain dust in farms, and dust and fumes in factories [76,77]. Already in 2003 the American Thoracic Society reported that 15\% of COPD cases could be attributed to occupational exposure in the workplace, and subsequent follow-up yielded similar results [78,79].

Lamprecht et al, reported that the risk of COPD attributable to agriculture was $7.7 \%$, and that $30 \%$ of the farmers in their study had COPD, at least minimal; and Edward and colleagues at a work in Norway, found that those exposed to livestock had a $40 \%$ higher risk than those who worked with crops, which was attributed to the high concentrations of ammonium, hydrogen sulphide and organic and inorganic dusts $[80,81]$. Other occupational exposures that have been associated with the risk of COPD are: coal mining, rock-hard mining, tunnel workers, concrete fabricators, exposure to silica in buildings, brick manufacturing, gold mining, iron and steel smelters [82,83].

Behrendt identified in the NHANES III other occupations associated with high prevalence of COPD such as manufacturing of plastics, textiles, rubber and leather as well as transport and trucking, manufacturing of food products, repair of automobiles and beauty care [22]. There has also been an increased prevalence of COPD in occupations associated with chronic exposure to diesel exhausts (eg, garages and mines) and other irritant gases and vapours [84].

\section{Chronic bronchial asthma}

Published reports indicate that there is a considerable number of patients $>50$ years of age who have obstructive airway disease with characteristics of asthma and COPD [85]. In 1961, Orie and colleagues postulated that asthma and COPD share a common background and the differentiation towards each of them could be modulated by environmental and host factors (Dutch hypothesis) [86]. The debate continues about whether COPD develops from asthma or whether both entities are completely independent (British hypothesis). Poorly treated chronic persistent asthma or severe asthma can cause changes in the lungs that are similar to those resulting from smoking, and the pattern of airway inflammation is similar to that in COPD, with increased in neutrophils, Interleukin-8, proteases and oxidative stress $[87,88]$. In a study in which 3099 patients were prospectively evaluated for 20 years, those with active asthma were 10 times more likely to develop symptoms of chronic bronchitis and 17 times more likely to be diagnosed with emphysema than those without asthma. Asthma was the strongest risk factor for subsequent COPD, more than even tobacco smoking (hazard ratio $12.5 \%$ vs $2.9 \%$, attributable risk $18.5 \%$ vs 6.7\%) [87]. Therefore, poor treatment of chronic and severe asthma worldwide, particularly in underdeveloped or developing countries, might substantially contribute to the burden of COPD.

Recently, in a joint effort of GINA and GOLD the term ACOS was developed as an overlap syndrome between asthma and COPD. ACOS definition is purely descriptive; it refers to a subgroup of patients with persistent airflow limitation that concomitantly shows several features, usually associated with asthma and several features usually associated with COPD. The fundamental point of identifying and appropriately treating these patients is that they seem to have a poorer prognosis [89]. ACOS patients frequently have exacerbations, poor quality of life, fast decline in lung function, increased mortality and they also consume 
more health resources than patients with asthma or COPD alone. In the sputum of these patients there are neutrophils and eosinophils and there is an urgent need to investigate in what extent this syndrome is the result of a change in the pathogenesis of asthma towards COPD over time (and should be titled only as ACO and not give it the character of a syndrome) or the entity has a different molecular biology and immunopathogenesis [90]. Around $25 \%$ of asthmatic patients smoke and these patients have a more severe asthma and a more rapid decline in lung function, which adds a higher risk factor to the probability of progressing to COPD [91]. It is likely that the exposure of asthmatics to biomass smoke carries the same risk although there are no studies that clarify this aspect.

\section{Pulmonary tuberculosis (PTB)}

PTB, a scourge since prehistoric times, affects more than 9 million people and kills 1.5 million people each year [92]. Prevalence of airflow obstruction varies from $28 \%$ to $68 \%$ of patients with PTB and the association occurs mainly with the COPD phenotype, at the diagnosis, during treatment and several years after treatment has ended [17]. Such infection is associated with airway fibrosis, and the immune response to mycobacteria can result in airway inflammation, which is characteristic of COPD. The degree of airflow obstruction is correlated with the extent of the disease.

In a nationwide survey of 13,826 adult in South Africa, results suggested that the strongest predictor of COPD was history of PTB: odds ratio 4.9 for men (95\% CI 2.6-9.2) and 6.6 (3.7-11.9) for women [29]. Furthermore, the risk of COPD was more strongly associated with PTB than with tobacco smoking or exposure to smoke from biomass fuel. The PREPOCOL study in 5 cities in Colombia reinforced the strong association of COPD with history of PTB (2.9, 1.6-5.5) [31] and the PLATINO study conducted in 5 in Latin American cities with a sample of 5571 patients also showed that the prevalence of COPD was $30.7 \%$ for patients with a history of PTB compared to $13.9 \%$ for those without [30]. History of PTB increased the risk of COPD by 4.1 times for men and 1.7 times for women.

More than 2 billion people (approximately one third of the world's population) are infected with mycobacterium tuberculosis and $80 \%$ of people infected live in 22 countries, with a particularly high burden in Asian, African and Latin American countries [93]. Therefore, it is likely that the cumulative burden of COPD associated with PTB is much greater than previously believed, particularly in developing countries. Whether this phenotype of COPD behaves similarly to COPD from smoking or biomass and what is the appropriate pharmacotherapy should be are has yet unknown.

\section{HIV/AIDS}

Pulmonary complications have been a major cause of morbidity and mortality in patients with HIV infection [94]. With the development of combination antiretroviral therapy (ARV) and improvement in prophylaxis for Pneumocystis pneumonia and other opportunistic infections, the incidence of infectious pulmonary complications has decreased drastically in patients with HIV infection [95]. Changes in non-infectious pulmonary complications, such as COPD and asthma, are less clear, and these diseases may actually be increasing. Studies before the introduction of combination ARV showed that people with HIV infection had a high prevalence of impaired diffusing capacity for carbon monoxide (DLCO), emphysema, accelerated airway obstruction and small airways disease, and more frequent respiratory symptoms than those not infected with HIV [96]. In the pre-ARV era, smoking and IV drug use were the major risk factors associated with pulmonary function symptoms and abnormalities, but the use of ARVs is associated with persistent and non-reversible obstruction of the airway as an independent risk factor Respiratory function tests are underutilized in these patients. Airway obstruction may the result of direct effects of the ARV drug. For example, ARV-associated cardiovascular disease and metabolic syndrome are thought because of ARV associated decreased expression of peroxisome-proliferatoractivated receptor. This receptor is an important transcription factor in lipid and cytokine metabolism and provides an anti-inflammatory effect in the lungs and airways, therefore, decreased levels might contribute to development of airway obstruction after ARV initiation [97]. Abnormal immune restoration similar to that in the immune reconstitution inflammatory syndrome may result in response to occult infection or colonization in the respiratory tract and lead to airway obstruction. Individuals with HIV infection are noted to have organ-specific autoimmune complications with ARV therapy, and another possibility is that autoimmune may occur in response to lung antigens after ARV treatment [97]. In 2015, 37 million people were reported alive with HIV infection worldwide and 4 million of them with COPD, with a prevalence of $10.2 \%$, the same as that of COPD in the general population associated primarily with high viral load (no CD4 +), smoking and high income. The presence of viral protein at the pulmonary levels might stimulate the recruitment of leucocytes into the respiratory tract. This stimulation could lead to the production of inflammatory cytokines and chemokines, as well as proteases that cause tissue destruction, airway thickening, and clinical expression of COPD. The absence of an association between CD4 cell count and COPD can be explained by the fact that tissue inflammation count in COPD is characterized by the predominance of neutrophils, CD8 cells, and macrophages infiltration, rather than CD4 cell count [98].

\section{Other significant associations}

Poor socioeconomic status is an independent risk factor associated with COPD, and seems to be an indicator of other possible factors such as intrauterine growth retardation, poor nutritional status (low antioxidant intake), respiratory tract infection in childhood, passive exposure to smoke of tobacco and biomass, and other indoor pollutants. These factors can contribute collectively to the risk of COPD [99].

Bronchopulmonary dysplasia is the most common chronic complication of extremely preterm birth, and the rate of this complication has remained stable or increased among extremely preterm infants in the past two decades. This complication is associated with high mortality rates, and among survivors it confers a predisposition to cardiovascular and chronic respiratory impairment, growth failure, and neurodevelopmental delay [100].

\section{Pathogenic mechanisms}

In COPD associated with cigarette smoking, the major pathogen that leads to inflammation is stress. Each inhalation of cigarette smoke contains about $10^{17}$ reactive oxygen species (ROS), which initiate the inflammatory response by stimulating macrophages and epithelial cells which in turn release chemotactic factors that attract other inflammatory cells to the lung and airway such as fibroblasts, neutrophils and $\mathrm{T}$ cells. They release mediators of inflammation creating a spiral that increases, amplifies and chronify the reaction [101]. Other types of stress are recognized as contributory to the pathogenesis of COPD such as inflammatory stress, endoplasmic reticulum stress, apoptotic stress, and nitrative stress. Oxidative stress 
can lead to the production of reactive carbonyls (carbonyl stress) which, when carbonyl proteins, make them immunogenic, generating an autoimmune process [102]. With biomass smoke, this ROS load can be derived both from the smoke as well as from the inflammatory cells recruited in the lung and airway. However, the information on the pathogenesis of the various types of COPD stress in non-smokers is not as clear or as abundant as in cigarette smokers, and studies are needed to demonstrate that interventions that increase endogenous antioxidant reserves may reduce or erase the toxic effects of ROS in the functions investigated [1]. However, if there are studies that have explored the association between oxidative stress and chronic exposure to biomass. Dutta and colleagues found increased production of ROS by exposure to biomass and decreased activity of superoxide dismutase (SOD) (an antioxidant enzyme) in epithelial cells and sputum leukocytes collected from chronically exposed rural women in India; findings that have been reproduced by Banerjee and Mukherjee [103-105]. Notably, generation of ROS was positively correlated, and SOD activity was inversely correlated with PM10 and PM2.5 levels in women's blood and also showed evidence suggestive of ROS attack to DNA from sputum isolated cells from rural women in India chronically exposed to biomass. The DNA attack test lies in the breaking of the acid bands. Ceylan and colleagues found significantly higher levels of DNA bands and an increase in serum levels of malondialdehyde and carbonylated proteins (used as markers of lipid and protein oxidation, respectively) [106]. However, other studies have not reproduced these conclusions and most probably this is related to the lack of standardization of the assays, the characteristics of the exposure to biomass and the cells and tissues examined. The axis: stress, autoimmunity and mitochondrial dysfunction already clearly involved in the pathogenesis of COPD associated with smoking has not been investigated in the COPD phenotype associated with biomass [107,108].

\section{Comparing the two types of COPD}

Very few studies have investigated the non-smoking phenotype of COPD or made comparisons with the smoking phenotype. Morán-Mendoza and colleagues found in their work that the clinical, functional, radiological and pathological findings are similar [109], however, Camp and colleagues found that exposure to biomass smoke was associated with less emphysema but with more air trapping than the associated smoking of tobacco, that is, a predominance of airway obstruction [110]. It should be taken into account that although it is true that many of the toxic products are common to both exposures such as the emissions of particulate matter and gases, there are also some substantial differences. For example, biomass from maize crop residue and animal dung can have bacterial endotoxins that amplify the toxic inflammatory process of gases and particles of matter. In addition, the inhalation pattern of both is usually very different. Inhalation of biomass smoke occurs with the spontaneous respiratory pattern of the patient, while cigarette smoke has two phases: first the smoke reaches the mouth without inhaling directly into the lung, and after a pause is inhaled with volume of approximately $25 \%$ of the vital capacity, that is twice the volume of the current air volume [110]. The higher inhalation volume of cigarette smoke compared to biomass smoke can deposit more tobacco smoke in the lung parenchyma leading to the predominantly emphysematous phenotype. The results in terms of survival are also dissimilar. Ramírez-Venegas and collaborators reported that Mexican women with COPD due to biomass had the same mortality as those who had COPD due to tobacco smoking [111], however, Shavelle and others showed that in US patients with COPD the reduction in the expectation of life was lower for those who had never smoked tobacco than those with COPD due to smoking [112]. Rivera and colleagues reported in necropsy studies of women with COPD that biomass smoke produced more pulmonary fibrosis, pigment deposit and thicker pulmonary artery intimas than those with COPD associated with smoking, which had greater emphysema and epithelial damage, which agrees with radiological findings and inhaling dynamics [113].

\section{Preventive interventions}

Studies that modify adverse respiratory outcomes from exposure to fuel smoke are limited. The most obvious way to eliminate exposure would be to turn to clean fuels such as electricity, but it is also obvious that this is not possible particularly in poorer and less educated countries. Some aid interventions reported mainly in developing countries are:

Replace the kitchens on the outside of the house. Women who cook outside of houses are exposed to a lower level of particulate matter than those who cook indoors [114]. Placing the kitchens in a space apart from the rest of the house decreases the exposure of other members in the home, although not the exposure of the kitchen [114], as well as adding additional windows to the space where cooking can reduce adverse respiratory effects [115].

Improving the design of the kitchens increases the efficiency in the thermal conversion, raises heat transfer radius and increases combustion (decreasing the emission of gases). Adding chimney to the stove improves the removal of smoke. Work done in highlands in Guatemala has shown that adding chimney to the kitchen, the plancha in Guatemala (chinamaste in Nicaragua and fogón in Costa Rica), reduces up to $50 \%$ exposure to $\mathrm{CO}$ and the incidence of pneumonia in children (45) and Chapman and others in a retrospective analysis, in China, have reported how the risk of COPD is reduced by improving the design of the kitchens [116]. Zhou and colleagues in a prospective study, also in China, showed that the use of biogas to cook and heat homes together with the improvement in the ventilation of kitchens can lead to reduce the global burden of COPD associated with the use of biomass. Biogas is a clean fuel produced by bacterial digestion of biodegradable materials [117].

\section{Future Directions}

The burden of COPD is increasing in both developed and underdeveloped and developing countries. In the US, $9 \%$ of young people between 12-17 years have used tobacco at some time and $28 \%$ of adults use it habitually. Smoking is responsible for more annual deaths than alcohol, illegal drugs, traffic accidents murders and suicides combined [118]. In Africa, the COPD prevalence defined spirometrically is $16.2 \%$ for the population in general and particularly high (39\%) between $20-39$ years. That is, a high prevalence in the young population. The mortality in the continent due to COPD exceeds the combined mortality due to malaria, tuberculosis and HIV/AIDS [28]. Therefore, while it is true that resources must be invested in designing strategies to reduce exposure to biomass, education should also be a priority for the population regarding the lethal effects of both exposures.

For ethical reasons there is no human model of controlled chronic exposure to biomass smoke and when analyzing the effect of environmental pollution, biomass smoke is only one of the constituents at risk, so there are errors of bias in some studies. There are also only some longitudinal and intervention works and usually the population samples are small, the evaluation of the results is inadequate, there are 
no adjustments for key covariates, inadequate knowledge of the basic mechanisms of production and the role of genetics and epigenetics affecting individual susceptibility in this COPD phenotype [34]. Little research has been done into the interaction of the various risk factors for COPD [17]. Therefore, these areas require future research. In vitro studies, studies in animals and in humans should be standardized so that the results are reliable and reproducible in non-smokers COPD. With respect to the markers of the various types of stress as a mechanism of COPD production in non-smokers, there are many in the literature. They should define future research which are best indicators of pathophysiological events.

The true burden for the different developing countries is not known as well as whether the prognosis is the same as for the COPD associated with smoking. It is not known if the cellular and immune profile is identical and finally if the treatment is the same. Almost all large trials of COPD have excluded non-smoking patients. All these aspects must be defined to adopt health policies that aim to reduce the burden of COPD not associated with smoking.

\section{Conclusions}

EPOC behaves like an adult pandemic, affecting more than $10 \%$ of the world's population, whether due to tobacco use in developed countries and the use of tobacco and/or pollution and other nonsmoking factors, in underdeveloped and developing countries. It is known the sub-registration of this entity in countries where spirometric diagnosis is not easily available, so this percentage could be higher on the planet.

The prevalence and mortality of the entity are increasing at a time when paradoxically we believe we know better the underlying inflammatory process and the factors that generate it. Several facts seem to be involved in this behavior but one of them may be COPD in non-smokers, an event that has increased and will continue to increase in the future related to low income and poor education.

The mechanisms, the cellular and immunological profile, the prognosis and the long-term complications as well as the best treatment for COPD in non-smokers are not clearly known, so resources should be invested in research in these areas

Intervention programs should be designed to modify the use of biomass fuels to control exposure. Given the projected increase in future mortality due to COPD, the weight of the evidence of what should be done is not available.

In the most affected countries, as well as educating the population on reducing smoking and vaccination against influenza viruses and pneumococcus, simple educational strategies should be designed to inform the population about the risk and how to reduce emissions and indoor and outdoor exposition.

\section{Author contribution}

This work was only carried out by the author. Author AA contributed in the planning, data collection, data analysis, writing and critical review. AA read and approved the final manuscript.

\section{Funding}

No

\section{Conflicts of interest}

No

\section{References}

1. Capistrano SJ, van Reyk D, Chen H, Oliver BG (2017) Evidence of biomass smoke exposure as a causative factor for development of COPD. Toxics.

2. Ito K, Ito M, Elliott WM, Cosio B, Caramori G, et al. (2005) Decreased histone deacetylase activity in chronic obstructive pulmonary disease. $N$ Engl J Med 352: 1967-1976.

3. Chen W, Brehm JM, Manichaikul A, Chao MH, Boutaoui N, et al (2015). A genomewide association study of chronic obstructive pulmonary disease in hispanics. Ann Am Thorac Soc 12: 340-348.

4. Decramer M, Janssens W, Miravalles M (2012) Chronic obstructive pulmonary disease Lancet 379: 1341-1351.

5. OSWALD NC, MEDVEI VC (1955) Chronic bronchitis; the effect of cigarettesmoking. Lancet 269: 843-844. [Crossref]

6. ANDERSON DO, FERRIS BG Jr (1962) Role of tobacco smoking in the causation of chronic respiratory disease. $N$ Engl J Med 267: 787-794. [Crossref]

7. Fletcher C, Peto R (1977) The natural history of chronic airflow obstruction. BMJ 1 1645-1648.

8. Kohansal R, Martínez-Camblor P, Augusti A, Buist AS, Mannino DM, et al (2009). The natural history of chronic airflow obstruction revisited: an analysis of the Framingham offspring cohort. Am J Respir Crit Care Med 180: 3-10.

9. Jha P, Ramasundarahettige C, Landsman V, Rostron B, Thun MJ, et al. (2013). 21 stcentury hazards of smoking and benefits of cessation in the United States. $N$ Engl J Med 368: 341-350.

10. Thun MJ, Carter BD, Feskanich D, Freedman ND, Prentice R, et al. (2013) 50-year trends in smoking-related mortality in the United States. $N$ Engl J Med 368: 351-364. [Crossref]

11. Zhou Y, Zhong N, Xiaochen L, Chen S, Zheng J, et al. (2017). Tiotropium in early-stage chronic obstructive pulmonary disease. N Engl J Med 377: 923-935.

12. Lozano R, Naghavi M, Foreman K, Lim S, Shibuya K, et al. (2012) Global and regiona mortality from 235 causes of death for 20 age groups in 1990 and 2010. A systematic analysis for the Global Burden of Disease Study 2010. Lancet 380: 2095-2128.

13. Wheaton AG, Cunningham TJ, For ES, Croft JB (2015) Employment and activity limitations among adults with chronic obstructive pulmonary disease-Unite States. MMWR Mor Mort Wkly Rep 64: 289-295.

14. GOLD (2015) Global Strategy for the Diagnosis, Management and Prevention of Chronic Obstructive Pulmonary Disease. Global Initiative for Chronic Obstructive Lung Disease.

15. Tashkin DP, Celli B, Senn S, Burkhart D, Kesten S, et al. (2008). A 4-year trial of tiotropium in chronic obstructive pulmonary disease. N Engl J Med 359: 1543-1554.

16. Wise RA, Anzueto A, Cotton D, Dahl R, Devins T, et al. (2013) Tiotropium Respimat inhaler and the risk of death in COPD. N Engl J Med 369: 1491-1501. [Crossref]

17. Salvi SS, Barnes PJ (2009) Chronic obstructive pulmonary disease in non-smokers Lancet 374: 733-743.

18. FAIRBAIRN AS, REID DD (1958) Air pollution and other local factors in respiratory disease. Br J Prev Soc Med 12: 94-103. [Crossref]

19. PHILLIPS AM (1963) THE INFLUENCE OF ENVIRONMENTAL FACTORS IN CHRONIC BRONCHITIS. J Occup Med 5: 468-475. [Crossref]

20. Husman K, Koskenvuo M, Kaprio J, Terho EO, Vohlonen I (1987). Role of environment in the development of chronic bronchitis. Eur J Respir Dis Suppl 152: 57-63.

21. Whittmore AS, Perlin SD, DiCiccio Y (1995) Chronic obstructive pulmonary disease in lifelong nonsmokers: results from NHANES. Am J Public Health 85: 702-706.

22. Behrendt CE1 (2005) Mild and moderate-to-severe COPD in nonsmokers: distinct demographic profiles. Chest 128: 1239-1244. [Crossref]

23. Birring SS, Brightling CE, Bradding P, James J, Entwisle D, et al (2002) Clinical, radiologic, and induced sputum features of chronic obstructive pulmonary disease in nonsmokers: a descriptive study. Am J Respir Crit Care Med 166: 1078-1083.

24. Pena VS, Miravalles M, Gabriel R, Jiménez-Ruiz CA, Villasante C, et al. (2000) Geographic variations in prevalence and underdiagnosis of COPD: results of the IBERPOC multicentre epidemiological study. Chest 118: 981-989.

25. Fukuchi Y, Nishimura M, Ichinose M, Adachi M, Nagai A, et al. (2004) COPD in Japan: the Nippon COPD Epidemiology study. Respirology 9: 458-465. [Crossref] 
26. Kim DS, Kim YS, Jung KS, Chang JH, Lim CM, et al. (2005). Prevalence of chronic obstructive pulmonary disease in Korea: a population-based spirometry survey. $A m J$ Respir Crit Care Med 172: 842-847.

27. Zhou Y, Wang C, Yao W, Chen P, Kang J, et al. (2009) COPD in Chinese nonsmokers. Eur Respir J 33: 509-518. [Crossref]

28. Van Gemert K, Kirenga B, Chavannes B, Kamuya M, Luzige S. et al (2015). Prevalence of chronic obstructive pulmonary disease and associated risk factor in Uganda (FRESH AIR Uganda): a prospective cross-sectional observational study. Lanc Glob Health 3: 44-51.

29. Ehrlich RI, White N, Norman R, Laubscher R, Steyn K, et al. (2004) Predictors of chronic bronchitis in South African adults. Int J Tuberc Lung Dis 8: 369-376. [Crossref]

30. Meneses AMB, Pérez-Padilla R, Jardim JRB, Muiño A, López MV, et al. (2005) For the PLATINO Team. Chronic obstructive pulmonary disease in five Latin American cities (the PLATINO study): a prevalence study. Lancet 366: 1875-1881.

31. Caballero A, Torres-Duque CA, Jaramillo C (2008) Prevalence of COPD in five Colombian cities situated at low, medium and high altitude (PREPOCOL study). Chest 133: $343-349$

32. Regional COPD Working Group (2003) COPD prevalence in 12 Asia-Pacific countries and regions: projections based on the COPD prevalence estimation model. Respirology 8: 192-198.

33. Widdicombe JH (2002) Regulation of the depth and composition of airway surface liquid. J Anat 201: 313-318.

34. Sood A (2012) Indoor fuel exposure and the lung in both developing and developed countries: an update. Clin Chest Med 33: 649-665. [Crossref]

35. World Health Organization (2011) Indoor Air Pollution and Health. WHO: Geneva, Switzerland.

36. Jain A, Ray S, Ganesan K, Aklin M, Cheng CY, et al (2016) Council on energy, environment and water. In Access to Clean Cooking Energy and Electricity: Survey of States in India (ACCESS); Council on Energy, Environment and Water: New Delhi, India.

37. Batteiger A, Rotter VS (2018) Material implications of rural electrification-a methodological framework to assess in-use stocks of Off-Grid Solar Products and EEE in rural household in Bangladesh. Recycling 3: 7 .

38. Gordon SB, Bruce NG, Grigg J, Hibberd PL, Kurmi OP, et al (2014). Respiratory risks from household air pollution in low and middle income countries. Lancet Respir Med 2: $823-860$.

39. Sussan TE, Ingole V, Kim JH, McCormick S, Negherbon J, et al. (2014) Source of biomass cooking fuel determines pulmonary response to household air pollution. $\mathrm{Am} J$ Respir Cell Mol Biol 50: 538-548. [Crossref]

40. López AD, Mathers CD, Ezatti M, Jamison DT, Murray CJL (2006) Global burden of diseases and risks factors. Washington DC: World Bank.

41. Lim SS, Vos T, Flaxman AD, Danaei G, Shibuya K, et al. (2012). A comparative risk assessment of burden of disease and injury attributable to 67 risk factor clusters in 21 regions, 1990-2010: A systematic analysis for the global burden of disease study 2010 . Lancet 380: 2224-2260.

42. Torres-Duque C, Maldonado D, Pérez-Padilla R, Ezzati M, Viegi G (2008) Forum of International Respiratory Studies (FIRS) Task Force on Health Effects of Biomass Exposure. Biomass fuels and respiratory diseases: a review of the evidence. Proc Am Thorac Soc 5: 577-590.

43. Saffari A, Daher N, Samara C, Voutsa D, Kouras A, et al (2013). Increased biomas burning due to the economic crisis in Greece and its adverse impact on wintertime air quality in Thessaloniki. Environ Sci Technol 47: 13313-13320.

44. Naeher LP, Brauer M, Lipsett M, Zelikoff JT, Simpson CD, et al (2007) Wood smoke health effects: A review. Inhal Toxicol 19: 67-106.

45. Smith KR, McCracken JP, Weber MW, Hubbard A, Jenny A, et al (2011). Effect of reduction in household air pollution on childhood pneumonia in Guatemala (RESPIRE): a randomized controlled trial. Lancet 378: 1717-1726.

46. Reisen F, Brown SK (2009) Australian firefighters' exposure to air toxics burns of autumn 2005 and 2006. Environ Int 35: 342-352.

47. Liu Y (2006) Where there's smoke there's lung disease. Thorax 62: 838-839.

48. Liu S, Zhou Y, Wang X, Wang D, Lu J, et al. (2007). Biomass fuels are the probable risk factor for chronic obstructive pulmonary disease in rural south China. Thorax 62 : 889-897.
49. Dennis RJ, Maldonado D, Norman S, Baena E, Martínez G, et al. (1999). Wood smoke exposure and risk for obstructive airways disease among women. Chest 109: 115-119.

50. Fullerton DG, Suseno A, Semple S, Kalambo F, Malamba R, et al. (2011) Wood smoke exposure, poverty and impaired lung function in Malawian adults. Int J Tuberc Lung Dis 15: 391-398. [Crossref]

51. Golshan M, Fagihi M, Marandi MM (2002) Indoor women jobs and pulmonary risks in rural areas of Isafaban, Iran. Respir Med 96: 382-388.

52. Kurmi OP, Devereux GS, Smith WC, Semple S, Steiner MF, et al (2013). Reduced lung function due to biomass smoke exposure in young adults in rural Nepal. Eur Respir $J$ 41: 25-30.

53. Regalado J, Pérez-Padilla R, Sansores R, Páramo-Ramírez JL, Braver M, et al. (2006) The effects of biomass burning on respiratory symptoms and lung function in rural Mexican women. Am J Respir Crit Care Med 174: 901-905.

54. Pérez-Padilla R, Regalado J, Veda IS, Pare P, Chapelan R, et al. (1996). Exposure to biomass smoke and chronic airway disease in Mexican women. A case-control study. Am J Respir Crit Care Med 154: 701-706.

55. Köksal H, Saygi A, Sariman N, AlIcI E, Yurtlu S, et al. (2013). Evaluation of clinical and functional parameters in female subjects with biomass smoke exposure. Respir Care 58: 424-430.

56. Sood A, Petersen H, Blanchette C, Meek P, Belinsky S, et al. (2009). Wood smokeassociated chronic obstructive pulmonary disease (COPD)-underappreciated in the United States? Am J Respir Crit Care Med 179: A4742.

57. Fullerton DG, Bruce N, Gordon SB (2008) Indoor air pollution from biomass fue smoke is a major health concern in the developing world. Trans $R$ Soc Trop Med Hyg 102: 843-851.

58. Kurmi OP, Lam KB, Ayres JG (2012) Indoor air pollution and the lung in low- and medium-income countries. Eur Respir J 40: 239-254. [Crossref]

59. Boy E, Bruce N, Delgado H (2002) Birth weight and exposure to kitchen wood smoke during pregnancy in rural Guatemala. Environ Health Perspect 110: 109-114. [Crossref]

60. Ezzati M, Lopez AD, Rodgers A, Vander Hoorn S, Murray CJ; Comparative Risk Assessment Collaborating Group (2002) Selected major risk factors and global and regional burden of disease. Lancet 360: 1347-1360. [Crossref]

61. Hancox RJ, Poulton R, Greene JM, MCLachlan CR, Pearce MS, et al. (2009). Associations between birth weight, early childhood weight gain and adult lung function. Thorax 64: 228-232

62. Rudan I, Boschi-Pinto C, Biloglav Z, Mulholland K, Campbell H (2008) Epidemiology and etiology of childhood pneumonia. Bull World Health Organ 86: 408-416. [Crossref]

63. Miller A (2013) Of dung and dynein arms: understanding COPD in nonsmokers. Respir Care 58: 543-545. [Crossref]

64. Holland WW, Reid DD (1965) The urban factor in chronic bronchitis. Lancet 285 1478-1485.

65. Lambert PM, Reid DD (1970) Smoking, air pollution, and bronchitis in Britain. Lancet 1: 853-857. [Crossref]

66. Burrows B, Kellogg AL, Buskey J (1968) Relationship of symptoms of chronic bronchitis and emphysema to weather and air pollution. Arch Environ Health 16: 406 413. [Crossref]

67. Kan H, Heiss G, Rose KM, Whitsel E, Lurmann F, et al. (2007). Traffic exposure and lung function in adults: the atherosclerosis risk in communities study. Thorax 62: 873-879.

68. Sunyer J, Jarvis D, Gotschi T, García-Esteban R, Jacquemin B, et al. (2006). Chronic bronchitis and urban air pollution in an international study. Occup Environ Med 63 836-843.

69. Gauderman WJ, Urman R, Avol E, Berhane K, McConnell R, et al. (2015) Association of improved air quality with lung development in children. $N$ Engl J Med 372: 905-913. [Crossref]

70. Dockery DW, Ware JH (2015) Cleaner air, bigger lungs. N Engl J Med 372: 970-972. [Crossref]

71. Balmes JR (2018) Where there's wildfire, there's smoke. N Engl J Med.

72. Song WJ, Faruqi S, Klaewsongkram J, Lee SE, Chang YS (2015) Chronic cough: an Asian perspective. Part 1: Epidemiology. Asia Pac Allergy 5: 136-144. [Crossref]

73. Johnston, FH, Purdie S, Jalaludin B, Martin KL, Henderson, SB, et al. (2014). Air pollution events from forest fires and emergency department attendances in Sydney, Australia 1996-2007: A case-crossover analysis. Environ. Health 13: 105. 
74. Martin KL, Hanigan IC, Morgan GG, Henderson B, Johnston H (2013) Air pollution from bushfires and their association with hospital admissions in Sydney, Newcastle and Wollongong, Australia 1994-2007. Aust. N. Z. J. Public Health 37: 238-243.

75. Trupin L, Earnest G, San Pedro M, Balmes MD, Eisner E, et al. (2003). The occupational burden of chronic obstructive pulmonary disease. Eur Respir J 22: 462-469.

76. Chester EH, Gillespie DG, Krause FD (1969) The prevalence of chronic obstructive pulmonary disease in chlorine gas workers. Am Rev Respir Dis 99: 365-373. [Crossref]

77. Becklake MR (1989) Occupational exposure: evidence for a causal association with chronic obstructive pulmonary disease. Am Rev Respir Dis 140: 585-591.

78. Balmes J, Becklake M, Blanc P, Henneberger P, Kreeis K, et al. (2003). Environmental and Occupational Health Assembly, American Thoracic Society. American Thoracic Society statement: occupational contribution to the burden of airway disease. $\mathrm{Am} \mathrm{J}$ Respir Crit Care Med 167: 787-797.

79. Blanc PD, Torén K (2007) Occupation in chronic obstructive pulmonary disease and chronic bronchitis: an update. Int J Tuberc Lung Dis 11: 251-257. [Crossref]

80. Lamprecht B, Schimhofer I, Kaiser B, Studnicka M, Buist AS, et al. (2007). Farming and the prevalence of nonreversible airway obstruction: results of a population-based study. Am J Ind Med 50: 421-426.

81. Eduard W, Pearce N, Douwes J (2009) Chronic bronchitis, COPD, and lung function in farmers: the role of biological agents. Chest 136: 716-725. [Crossref]

82. Ulvestad B, Bakke B, Edward W, Kongerud J, Lund MB (2001) Cumulative exposure to dust causes accelerated decline in lung function in tunnel workers. Occup Environ Med 58: 663-669.

83. Rushton J (2007) Chronic obstructive pulmonary disease and occupational exposure to silica. Rev Environ Health 22: 255-272.

84. Weinmann S, Vollmer WM, Breen V, Heumann M, Hnizdo E, et al. (2008) COPD and occupational exposures: a case-control study. J Occup Environ Med 50: 561-569. [Crossref]

85. Soriano JB, Davis KJ, Coleman B, Visick G, Mannino D, et al. (2003). The proportional Venn diagram of obstructive lung disease: two approximations from the United States and United Kingdom. Chest 124: 474-481.

86. Orie N, Sluiter H, de Vries K. (1961). The host factor in bronchitis. In: Orie N, Sluiter H (Eds) Bronchitis. The Netherlands: Royal Van Gorcum pp: 43-59.

87. Silva GE, Sherrill DL, Guerra S, Barbee RA (2004) Asthma as a risk factor for COPD in a longitudinal study. Chest 126: 59-65. [Crossref]

88. Barnes PJ (2006) Against the Dutch hypothesis: asthma and chronic obstructive pulmonary disease are distinct diseases. Am J Respir Crit Care Med 174: 240-243.

89. Diagnosis of Asthma, COPD, and Asthma-COPD Overlap Syndrome (ACOS) (2016) A joint project of GINA and GOLD.

90. Postma DF, Rabe KF (2015) The Asthma-COPD Overlap Syndrome. $N$ Engl J Med 373: $1241-1249$

91. Yang JA, Fong KM, Sim EH, Black PN, Lasserson TJ (2007) Inhaled corticosteroids for stable chronic obstructive pulmonary disease. Cochrane Database Syst Rev 18 CD002991.

92. Horsburgh CR, Barry CE, Lange C (2015) Treatment of Tuberculosis. N Engl J Med 373: 2149-2160. [Crossref]

93. WHO Stop TB Partnership (2018) Tuberculosis in countries.

94. Palella FJ Jr, Delaney KM, Moorman AC, Loveless MO, Fhurer J, et al. (1998). Declining morbidity and mortality among patients with advanced human immunodeficiency virus infection. HIV Outpatient Study Investigators. N Engl J Med 338: 853-860.

95. Palella FJ Jr, Baker RK, Moorman AC, Chmiel JS, Wood KC, et al (2006). Mortality in the highly active antiretroviral therapy era: changing causes of death and disease in the HIV outpatient study. J Acquir Immune Defic Syndr 43: 27-34.

96. Díaz PT, Wewers MD, Pacht E, Drake J, Nagaraja HN, et al. (2003). Respiratory symptoms among HIV-seropositive individuals. Chest 123: 1977-1982.

97. Gingo MR, George MP, Kessinger CJ, Lucht L, Rissler B, et al (2010). Pulmonary function abnormalities in HIV-infected patients during the current antiretroviral therapy era. Am J Respir Crit Care Med 182: 790-796.

98. Bigna JJ, Keene AM, Asangbeh SL, Sibetchev A. (2018). Prevalence of chronic obstructive pulmonary disease in the global population with HIV: a systematic review and meta-analysis. Lanc Glob Health 6: e193-e202.
99. Hegewald MJ, Crapo RO (2007) Socioeconomic status and lung function. Chest 132: 608-614.

100. Bassler D, Shinwell ES, Hallman M, Jarreau PH, Plavka R, et al. (2018) Long-Term Effects of Inhaled Budesonide for Bronchopulmonary Dysplasia. N Engl J Med 378: 148-157. [Crossref]

101. Alvarado A, Arce I (2015) Molecular biology of chronic obstructive pulmonary disease from the bases to the therapeutic decision: a review. $\mathrm{Br} J$ Med Medic Res 10: $1-14$.

102. Eggleton P, Haigh R, Winyard PG (2008) Consequence of neo-antigenicity of the 'altered self'. Rheumatology (Oxford) 47: 567-571. [Crossref]

103. Banerjee A, Mondal NK, Das D, Ray MR (2012) Neutrophilic inflammatory response and oxidative stress in premenopausal women chronically exposed to indoor air pollution from biomass burning. Inflammation 35: 671-683.

104. Mukherjee B, Dutta A, Roychoudhury S, Ray MR (2013) Chronic inhalation of biomass smoke is associated with DNA damage in airway cells: Involvement of particulate pollutants and benzene. J App Toxicol 33: 281-289.

105. Dutta A, Roychoudhury S, Chowdhury S, Ray MR (2013) Changes in sputum cytology, airway inflammation and oxidative stress due to chronic inhalation of biomass smoke during cooking in premenopausal rural Indian women. Int J Hyg Environ Health 216: 301-308.

106. Ceylan E, Kocygit A, Gencer M, Aksoy N, Selek E (2006) Increased DNA damage in patients with chronic obstructive pulmonary disease who had once smoked or been exposed to biomass. Respir Med 100: 1270-1276

107. Kang MJ, Yoon CM, Kim BH, Lee CM, Zhou Y, et al. (2015) Suppression of NLRX1 in chronic obstructive pulmonary disease. J Clin Invest 125: 2458-2462.

108. McCarthy CE, Duffeney PF, Wyatt DJ, Thatcher TH, Phipps RP, et al. (2017) Comparison of in vitro toxicological effects of biomass smoke from different source of animal dung. Toxicol in Vitro 43: 76-86.

109. 109) Moran-Mendoza O, Pérez-Padilla JR, Salazar-Flores M, Vásquez-Alfaro F. (2008). Wood smoke-associated lung disease: a clinical, functional, radiological and pathological description. Int J Tuberc Lung Dis. 12:1092-1098.

110. Camp PG, Ramirez-Venegas A, Sansore RH, Alval F, Mc Dougall JE, et al. (2014). COPD phenotypes in biomass smoke-versus tobacco smoke-exposed Mexican women. Eur Respir J 43: 725-734.

111. Ramírez-Venegas A, Sansore RH, Pérez-Padilla R, Regalado J, Velásquez H, et al (2006). Survival of patients with chronic obstructive pulmonary disease due to biomass smoke and tobacco. Am J Respir Crit Care Med 173: 393-397.

112. Shavelle RM, Paculdo DR, Kush SJ, Mannino DM, Strauss J (2009) Life expectancy and years of life lost in chronic obstructive pulmonary disease: findings from the NHANES III follow-up study. Int J Chron Obstruct Pulmon Dis 4: 137-146.

113. Rivera RM, Cosio MG, Ghezzo H, Salazar M, Pérez-Padilla R (2008) Comparison of lung morphology in COPD secondary to cigarette and biomass smoke. Int J Tuberc Lung Dis 12: 972-977. [Crossref]

114. Balakrishnan K, Sankar S, Parikh J, Padmavathi R, Srividya K, et al. (2002). Daily average exposure to respirable particulate matter from combustion of biomass fuels in rural households of southern India. Environ Health Perspect 110: 1069-1075.

115. Kodgule R, Salvi S (2012) Exposure to biomass smoke as a cause for airway disease in women and children. Curr Opin Allergy Clin Immunol 12: 82-90.

116. Chapman RS, He X, Blair AE, Lan Q (2005) Improvement in household stoves and risk of chronic obstructive pulmonary disease in Xuanwel, China: retrospective cohort study. BMJ 331: 1050 .

117. Zhou Y, Zou Y, Li X, Chen S, Zhao Z, et al. (2014). Lung function and incidence of chronic obstructive pulmonary disease after improvement cooking fuel and kitchen ventilation: a 9 year prospective cohort study. PLoSMed 11: e 1001621.

118. Kassa KA, Ambrose BK, Conway KP, Borek N, Taylor K, et al. (2017). Tobaccoproduct use by adults and youths in the United States in 2013 and 2014. $N$ Engl J Med 376: 342-353.

Copyright: (C2018 Alvarado A. This is an open-access article distributed under the terms of the Creative Commons Attribution License, which permits unrestricted use, distribution, and reproduction in any medium, provided the original author and source are credited. 